【論 文】

UDC : $691.32: 666.973 .6$

\title{
繊維複合した軽量気泡コンクリートの破壊靶性 および AE スペクトラム解析
}

\section{1. 序}

建築材料として現在広く使われている ALC は，軽量 性，耐火性および断熱性等の優れた性質を有している。 しかし，ALCマトリックスの比重は普通コンクリート の約 4 分の 1 であるため，機械的性質は弱く脆い。特に 脆性は ALC はもとよりセメントモルタル，コンクリー 卜等の無機材料にとって本質的な短所である。この短所 を補う目的で従来からセメントモルタル，コンクリート では種々の繊維を複合させ, 物性の改良・改質を行って きている1)。したがって，ALCの脆性を改良するため にも，繊維複合化は妥当な手段である。

一方，靶性脆性を評価する破壊靶性試験は金属材料に おいて確立されている2),3)。セメントコンクリート材料 でも，いままで耐圧縮構造材として扱われてきたが, 最 近破壊力学的な研究, 特に, 破壊靵性および破壊機構に 関する研究は近年盛んに行われてきている4) 8)。和泉ら は，コンクリートの破壊を巨視的レベル，準巨視的レベ ル，微視的レベルに分けて，破壊靭性評価および破壊機 構の解明の重要性を述べている ${ }^{9)}$ 。すなわち, 圧縮荷重 下においても局所的には，大きな引張り応力が発生し， この局所的引張り応力が，準巨視的クラックの進展を引 き起こし，それらの合体・連結によって巨視的な破壊を 引き起こす。したがって，局所的応力およびき裂伝播特 性を知るうえで破壊鞋性評価が重要である。

しかしながら，ALC を破壊力学的に評価した研究は 少ない。F.H. Wittmann らは，ALC の切欠き三点曲 げ試験, CT 試験等を行い， $K_{I c}$ を求め,この值が圧縮 強度と比例関係にあると述べている ${ }^{10)}$ 。しかし，Kによ る評価は線形破壊を示す材料に適用されるものである。 換言すれば，き裂先端近傍の塑性領域が小さい範囲にお いて適用される。ALCの場合，コンクリート材料と同 様に非線形破壊を示す材料であるため，また，本研究の 繊維複合した材料の場合には，その非線形挙動がますま す顕著になることが予想されるため，Jによる評価が妥 当であると考えられる。

しかし，コンクリート材料の $J$ を評価する場合，次

* 小野田エー・エル・シー(株) 開発研究所 研究員 (昭和 62 年 3 月 10 日原稿受理)
正会員寺 村 敏 史*

の問題点がある。すなわち,（1）脆性的なクラック伝 播に先立って発生する安定なクラックの長さを明確に測 定することが困難である。（2）コンクリート材料での クラックは単一クラックから進展するものよりはるかに 複雑である9 ${ }^{9)}$ そのため, アコースティック・エミッショ ン $(\mathrm{AE})$ 法によってクラックの発生・進展を検出する 試みがなされてきており，AE 法が有効な手段であるこ とが多く報告されている(1) -13)。

$\mathrm{AE}$ 法は従来 $\mathrm{AE}$ 発生率, 発生エネルギーの計測およ び発生位置評定が主であったが, 最近 AE スペクトラ ムによる解析が注目されつつあり, 金属 ${ }^{14)}$, コンクリー $卜^{15)}$ ，木材等 ${ }^{16) .17)}$ において破壊機構を解明するうえでの 手法として研究されてきている。しかし，これらの材料 より複雑な破壊機構を持つ繊維複合材料についてはまだ 行われていない。

本報告は，木質繊維および耐アルカリガラス繊維を用 いて試作した瀻維複合 ALC (以下, 各々の試験体を WRALC，GRALC と呼ぶ。）のAE 法を併用した切欠 き三点曲げ破壊鞋性試験を行い，鞀性評価をするととも に，AEスペクトラムと破壊機構との対応を述へ，さら に両繊維複合 ALC の複合効果についても述べる。

\section{2. 実験方法}

\section{1. 試験体}

図一1 に繊維複合 ALC 試験体作製のプロセスを示し た。また，使用した原料の配合を表一1に，使用した耐 アルカリガラスおよびパルプ繊維の性状等を表一2に示 した。短瀻維をマトリックス中にランダム配列させる場 合，その均一性が問題となる。本研究では打設時のスラ リー, 硬化体の加工面および試験後の破断面を観察する ことによって繊維が均一に単繊維でマトリックスに複合 化されていることを確認した。

繊維の添加量はALC の発泡が困難にならない程度, すなわち，全原料の重量に対して $2.0 \mathrm{wt} \%$ までとした。 表一3に本実験の試作条件および作製された各々の材料 の圧縮強度，曲げ強度および X 線回折によるトバモラ イトの [002] のピークの相対高さを示す。トバモライ トは ALC 硬化体を形成するケイ酸カルシウム水和物で あり，ALCにおいてトバモライト生成量と圧縮強度等 


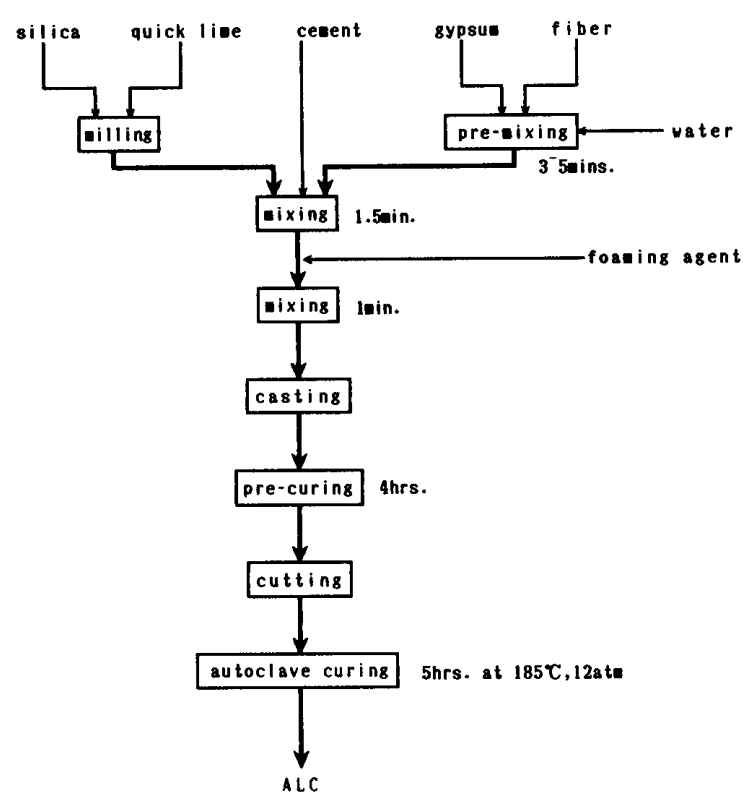

図一1 織維複合 ALC 試験体作製プロセス

表一1 試作 ALC の原料配合

\begin{tabular}{l|cccc}
\hline $\begin{array}{c}\text { starting } \\
\text { material }\end{array}$ & silica & quick lime & cement & gypsum \\
\hline $\begin{array}{l}\text { weight } \\
\text { percentage }\end{array}$ & 60 & 17 & 20 & 3 \\
\hline
\end{tabular}

\begin{tabular}{|c|c|}
\hline wood fiber & $\begin{array}{c}\text { alkaline-resistance } \\
\text { glass fiber }\end{array}$ \\
\hline $\begin{array}{l}\text { name } \\
\text { samoa pulp }\end{array}$ & \\
\hline $\begin{array}{l}\text { place of manufacture } \\
\text { Saloa, Cal i fornia, } \\
\text { U.S.A. }\end{array}$ & \\
\hline $\begin{array}{l}\text { wood species } \\
\text { Redwood } \\
\text { Douglas fir. } 20-30-80 \%\end{array}$ & \\
\hline form & $\begin{array}{l}\text { form } \\
\text { chopped strand }\end{array}$ \\
\hline $\begin{array}{l}\text { length } \\
\text { approx. } 3.0 \mathrm{n}\end{array}$ & $\begin{array}{l}\text { length } \\
10 \text { and }\end{array}$ \\
\hline $\begin{array}{l}\text { diameter } \\
\text { approx. } 20 \mu \mathrm{m}\end{array}$ & $\begin{array}{l}\text { diameter } \\
\text { approx. } 20 \mu \mathrm{m}\end{array}$ \\
\hline $\begin{array}{l}\text { density } \\
\text { approx. } 0.68 / \mathrm{cm}^{\circ}\end{array}$ & $\begin{array}{l}\text { density } \\
\text { approx. } 2.7 \mathrm{~g} / \mathrm{cm}^{3}\end{array}$ \\
\hline $\begin{array}{r}\text { tensile strength } \\
\text { (after autoclaving) } \\
\text { approx. } 20 \mathrm{~kg} / \mathrm{mm}^{2}\end{array}$ & $\begin{array}{r}\text { tensile strength } \\
\text { (after autoclaving) } \\
\text { approx. 50kg/m. }\end{array}$ \\
\hline
\end{tabular}

の機械的性質とは良い相関関係を持つことが知られてい る $^{18)}$ 。

切欠き三点曲げ破壊勒性試験に供するため図一 2 に示 した寸法に切出した。切欠きの最終仕上げは $0.3 \mathrm{~mm}$ 厚 さのカーボンブレードを用い，切欠き先端に加工による 微視き裂が発生しないよう乾式で手動で注意深く行っ た。

\section{2. 测定装置}

図一 3 に切欠き三点曲げ破壊靫性試験装置のブロッ ク・ダイアグラムを示す。試験体の切欠き肩部にはその 開口変位 $\left(V_{\boldsymbol{g}}\right)$ を測定するためクリップゲージを取り
表一3 瀻維複合 ALC の試作条件およびその圧縮強度，曲げ強 度，およびX 線回折によるトバモライト [002] ピーク の相対高さ（瀻維複合していない ALC のピーク高さを 100 とする。)

\begin{tabular}{|c|c|c|c|c|c|c|}
\hline fiber & $\begin{array}{l}\text { fiber lensth } \\
\text { (II) }\end{array}$ & $\begin{array}{c}\text { fiber content } \\
\text { (weight } \$)\end{array}$ & $\begin{array}{l}\text { compressive } \\
\text { strensth } \\
\text { (ke/(m) }\end{array}$ & $\begin{array}{l}\text { bending } \\
\text { strenth } \\
\left.\text { (kg/ } \mathbf{m}^{2}\right)\end{array}$ & $\begin{array}{l}\text { density } \\
\left(z / c u^{8}\right)\end{array}$ & $\begin{array}{l}\text { Tobermori ite } \\
\text { [002] deakk }\end{array}$ \\
\hline \multirow[t]{4}{*}{ 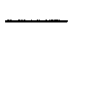 } & 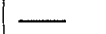 & - & 52.7 & 14.2 & 0.50 & 100 \\
\hline & & 0.5 & 50.3 & 13.8 & 0.51 & 97 \\
\hline & 1.5 & 1.0 & 51.4 & 13.8 & 0.52 & 97 \\
\hline & & 1.5 & 50.1 & 12.5 & 0.49 & 100 \\
\hline \multirow[t]{3}{*}{ nood fiber } & & 2.0 & 52.0 & 13.8 & 0.53 & 103 \\
\hline & 3.0 & 1.0 & 53.4 & 14.0 & 0.52 & 103 \\
\hline & & 2.0 & 57.2 & 14.4 & 0.54 & 103 \\
\hline \multirow{2}{*}{$\begin{array}{l}\text { al kal ine- } \\
\text { resistance } \\
\text { glass fiber }\end{array}$} & 10.0 & 1.0 & 53.3 & 13.2 & 0.53 & 103 \\
\hline & & 2.0 & 54.8 & 14.2 & 0.53 & 97 \\
\hline
\end{tabular}
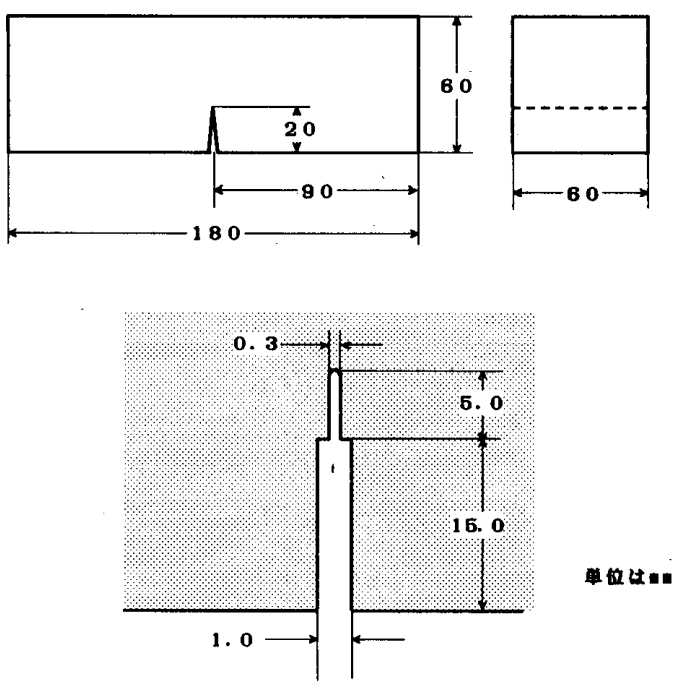

図一2 試験体寸法（上図）および切欠きの形状（下図）

付けた。 $\mathrm{AE}$ トラムスデューサーは PAC 製の広帯域セ ンサーを用い, 試験体側面の切欠き先端から約 $10 \mathrm{~mm}$ 離れた部分に接着した。また，スパン中央変位 $\left(V_{L}\right)$ をクリップゲージで測定した。この時図一4に示すよう に支持部での試験片の塑性変形によるへこみを考慮した 測定方法を採用した。すなわち，式（1）に示したよう に $V_{L}$ は，スパン中央部と下部支持台との間の変位 $\left(V_{L}^{\prime}\right)$ から下部支持点とその支持上部の式験体（本実験では， 試験体底部から約 $5 \mathrm{~mm}$ 上部 $)$ との間の変位 $\left(V_{D}\right)$ を引 いた値とした。

$$
V_{L}=V_{L}^{\prime}-V_{D}
$$

試験機はインストロン製の定変位載荷試験機を用い, クロスヘッド速度 $0.05 \mathrm{~mm} / \mathrm{min}$, スパン $160 \mathrm{~mm}$ で行っ

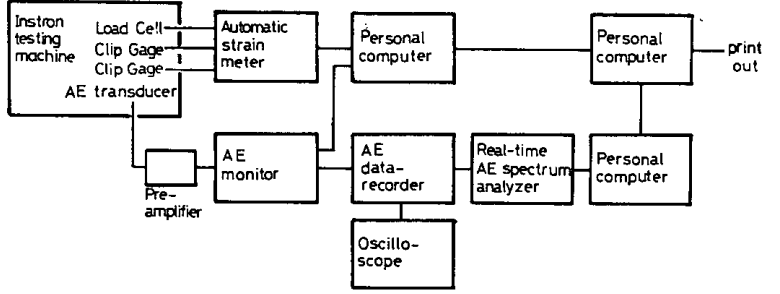

図一－3切欠き三点曲げ破壊靶性試験装置のブロックダイアグラ 么 


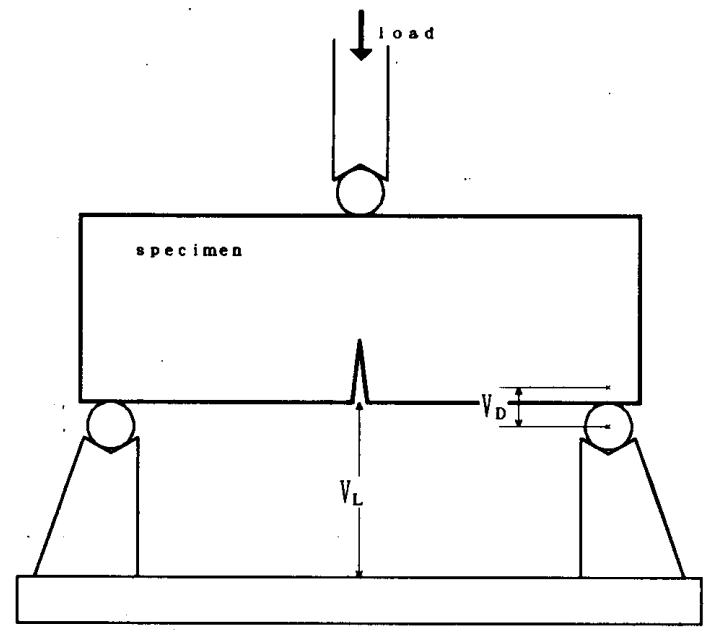

図一4 スパン中央変位 $\left(V_{L}\right)$ の測定法

下部支持点でのへこみを考慮して， $V_{L}=V_{L}^{\prime}-V_{D}$ とした。

た。 $\mathrm{AE}$ の総合利得は $70 \mathrm{~dB}$ で, $\mathrm{AE}$ 信号は出力電圧を 8 段階に分けたイベントデータとしてパソコンに試験時 の荷重, 開口変位およびスパン中央変位のデータととも にリアルタイムで入力した。

また, $\mathrm{AE}$ 周波数解析を行うため $\mathrm{AE}$ 信号を VTR 型 のデータレコーダーに収録した。本試験では新しく開発 された $\mathrm{AE}$ 自動周波数解析装置を用いて $10 \sim 500 \mathrm{kHz}$ の帯域で $\mathrm{AE}$ スペクトラムを得た*199),20)。従来, $\mathrm{AE}$ 周 波数解析はデーターレコーダーに収録した AE 信号を ひとつづつFFT アナライザーにかけスペクトラムを得 るアナログ方式かウェーブメモリーに記憶させ FFT ア ナライザーにかけるデジタル方式がとられていた。両者 の方法には一長一短がある。アナログ方式は長期の監視 には適しているが, 解析には時間と労力を要する。一方, デジタル方式は解析に要する時間および労力はアナログ 方式に比して短縮されるが, 記憶容量に問題があり, 長 期監視および $\mathrm{AE}$ 事象の多い場合にはその装置費用が 高くなる。本実験で用いた $\mathrm{AE}$ 自動周波数解析装置は 新しいパイプライン方式を採用しリアルタイムにスペク トラムに変換し、コンピューター等の外部記憶装置に記 録できるため, 特に複合材料の試験のように $\mathrm{AE}$ 事象 数が多い測定に非常に効果を発揮する。

\section{3. 実験結果}

\section{1. 破壊靫性試験結果}

切久き三点曲げ破壊勒性試験より得られた荷重一切欠 き肩部開口変位曲線を図一 5 に示す。繊維長 $1.5 \mathrm{~mm}$ の WRALC の最大荷重までの挙動はALC とほとんど変 らない。しかし，最大荷重以降の挙動は繊維添加量が増 加するにしたがって開口変位が増加してもなかなか荷重 低下しない傾向になる。この傾向は瀻維長 $3.0 \mathrm{~mm} の$ WRALC では繊維長 $1.5 \mathrm{~mm}$ の WRALC より顕著であ り, かつ添加量 $2.0 \mathrm{wt} \%$ の時の大きな非線形挙動を示 し, 最大荷重はALC の約 2 倍と著しく向上している。

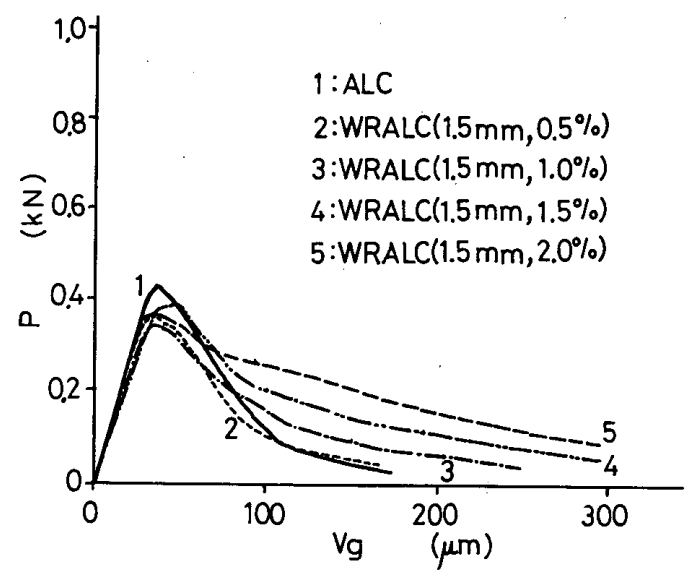

(a) 織稚長 $1.5 \mathrm{~mm}$ の WRALC

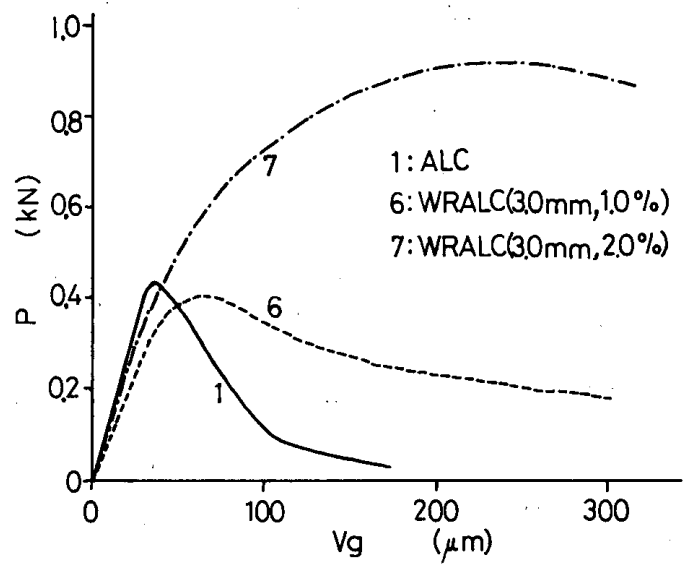

(b) 織維長 $3.0 \mathrm{~mm} の$ WRALC

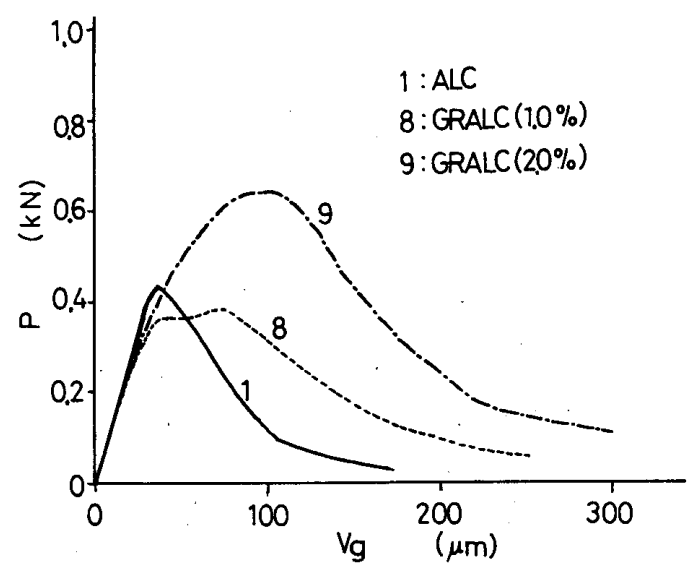

(c) 瀻維長 $10 \mathrm{~mm} の$ GRALC

図一5 荷重一切欠き肩部開口変位 $\left(V_{g}\right)$ 線図

一方，GRALC では荷重降下時の挙動は WRALC より やや劣り, また最大荷重は添加量 $2.0 \mathrm{wt} \%$ で ALC の 約 1.5 倍程度である。

荷重変位曲線から明らかなように，これらは非線形挙 動を呈する材料であるため, 応力拡大係数 $K$ による評 価より $J$ 積分によって靶性值を求めるほうが妥当であ る。 $J$ 積分は次式により求めた2。

$$
J=\frac{A}{B b_{0}} f\left(\frac{a_{0}}{W}\right)
$$


ここで, $A$ は, 荷重一荷重線変位曲線下の面積であり, 各測定点でつくられる台形の面積の累計によって近似し た。 $B$ は試験片厚さ，W は試験片幅， $a_{0}$ は予き裂長さ, $b_{0}$ はリガメント幅 $\left(W-b_{0}\right)$ である。 $f\left(a_{0} / W\right)$ はこ こでは 2.0 とした。

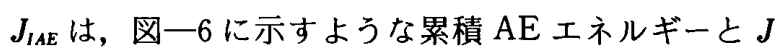
積分値との対数線図において 2 直線で近似した場合の交 点における $J$ 積分値である。この点は $\mathrm{AE}$ 発生の急増 点で，AE 法で定めた予き裂先端における巨視的き裂成 長開始点である。この $J_{I A E}$ は, 金属材料において他の 方法で定めた $J_{I C}$ とほぼ一致する ${ }^{2)}$ 。コンクリート材料 においても $\mathrm{AE}$ 発生の急増点は確認されており4)，また 本実験におけるALC 材でも検出されている。ALC 材 において他の方法で定めた $J_{I C}$ との対応は確認されてい ないが, $\mathrm{AE}$ 発生急増点での $J$ 值として取り挙げる。

$J_{\rho \max }$ とは最大荷重での $J$ 積分値であり, 最大荷重点 までに要したエネルギーを $J$ 值としてとらえたもので ある。

また，簡便な評価法として荷重降下時間 $\left(T_{s}\right)$ を提 案する。図一7 に示すように荷重降下時間は, 最大荷重 から最大荷重の 2 分の 1 に降下するまでの時間を表して いる。このパラメータは, 同一試験体寸法で同一載荷速 度においてのみ比較評価ができる。しかし，き裂進展抵 抗を測定するための品質管理上の簡便法になりうるもの である。

図一8, 9 および 10 に各々 $J_{I A E}, J_{\rho \max }$ および荷重降下

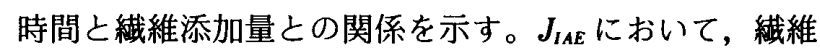
添加量とともに増加する傾向がみられるのは $3.0 \mathrm{~mm}$ 瀻 維長のWRALC のみであり，1.5 mm 繊維長の WRALC および GRALC は繊維添加量の増加に伴い若 干の低下がみられる。 $J_{p \max }$ は, $1.5 \mathrm{~mm}$ 䋐維長の WRALC は $J_{I A E}$ とおなじように繊維添加量が増加して も変らないが, GRALC は増加傾向がみられる。3.0 $\mathrm{mm}$ 織維長の WRALC は, 特に $2.0 \mathrm{wt} \%$ で ALC の約

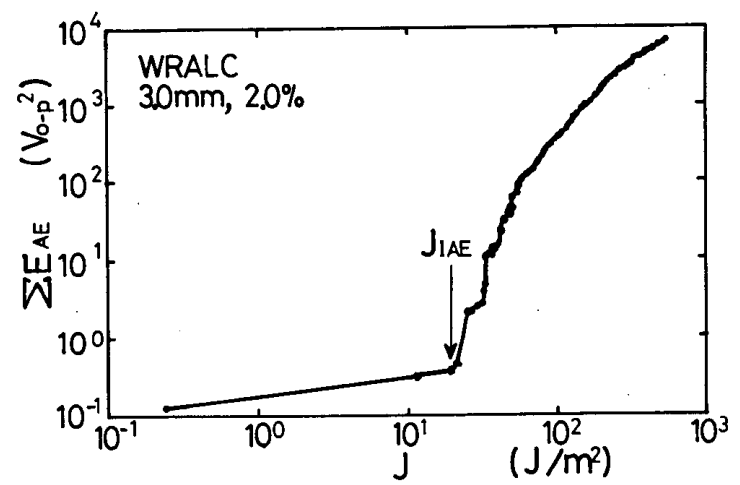

図一6 $J-\sum E_{A E}$ 線図の一例（繊維長 $3.0 \mathrm{~mm}$, 添加量 $2.0 \%$ の WRALC)

この線図を 2 直線に近似したとき，その交点を $J_{\boldsymbol{I A E}}$ と する。
15 倍向上しているのがわかる。荷重降下時間はすべて の繊維において繊維添加量とともに増加しており, 繊維 複合がき裂進展抵抗を大きくしていることがわかる。そ の効果は, $3.0 \mathrm{~mm}$ 繊維長のパルプ繊維, $1.5 \mathrm{~mm}$ 繊維 長のパルプ繊維, 耐アルカリガラス繊維の順である。

3.2. AE イベントおよびスペクトラムからみた繊維 複合 ALC

累積 $\mathrm{AE}$ イベント数と瀻維添加量との関係を図一11 に示す。ここで累積 $\mathrm{AE}$ イベント数は, 載荷開始から 最大荷重を経てその 2 分の 1 荷重に降下した時点までに 発生した総数をいう。この関係も瀻維添加量とともに増 加する傾向がみられるが，ここで上述した $J_{I A E}$ 等の関 係と異なる点は, 累積 $\mathrm{AE}$ イベント数の増加分は 3.0

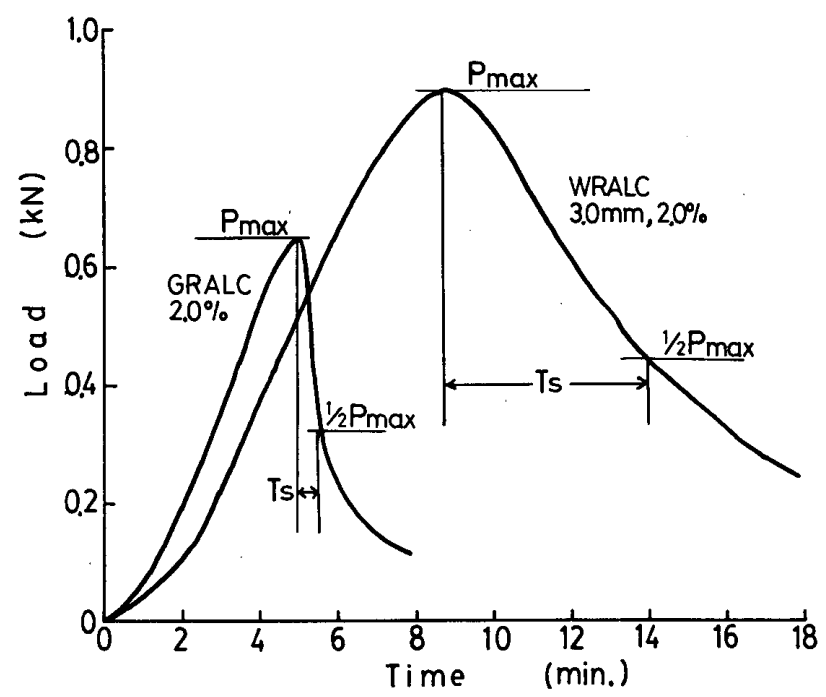

図一7切久き三点曲げ破壊勒性試験での荷重一時間曲線 荷重降下時間 $\left(T_{s}\right)$ は最大荷重点から最大荷重の 2 分 の 1 まで降下するのに要する時間を言う。

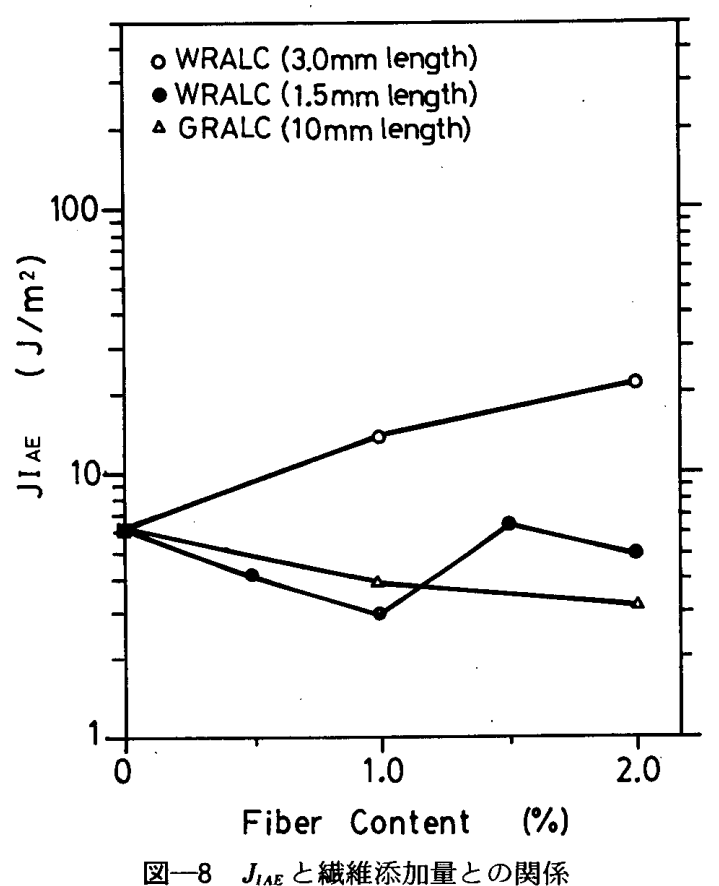




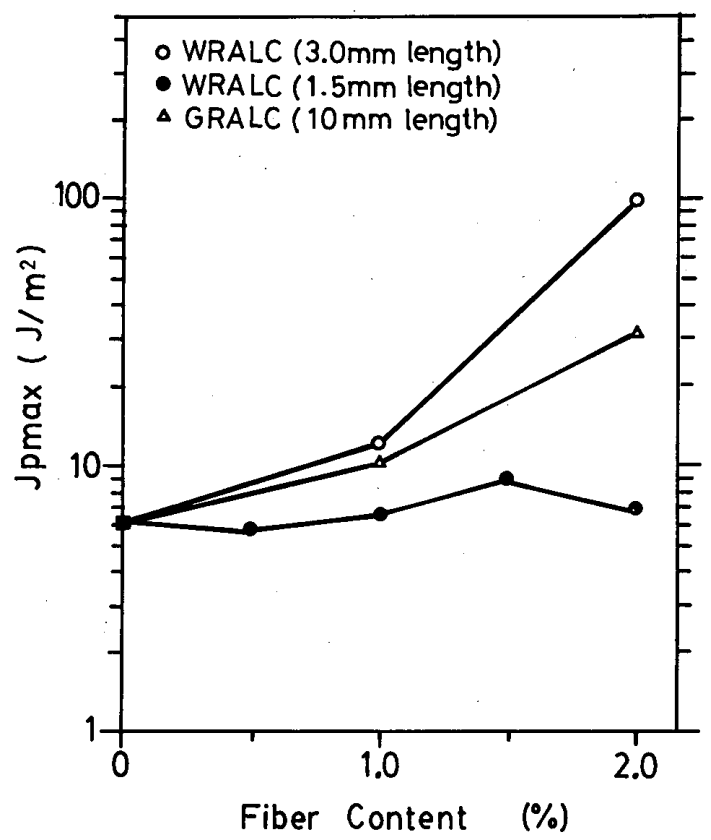

図一9 $J_{\rho \max }$ と繊維添加量との関係

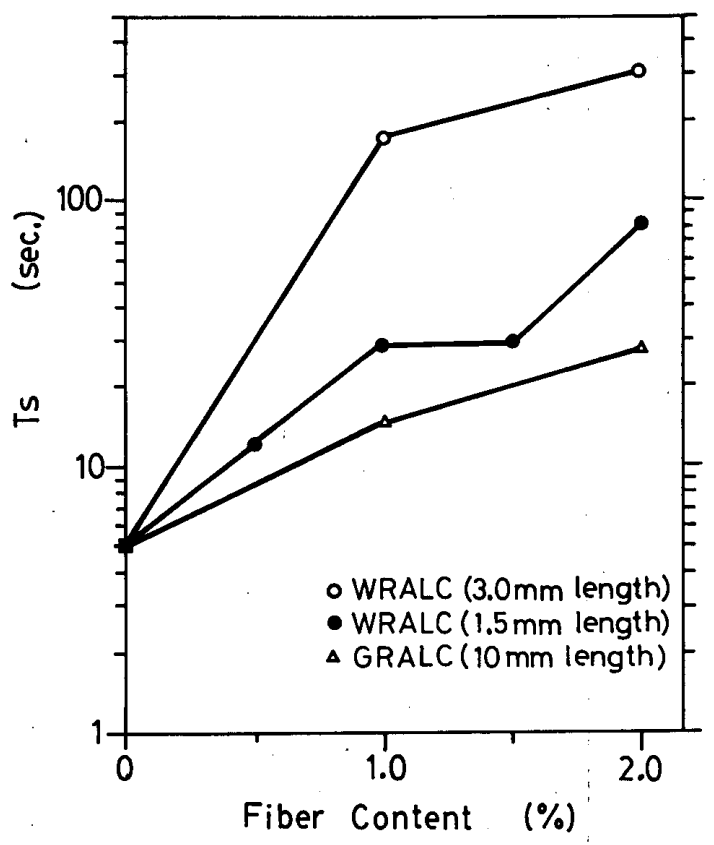

図一10 荷重降下時間と繊維添加量との関係

$\mathrm{mm}$ 繊維長の WRALC より GRALC のほうが大きいこ とである。これは, 後述するが, 繊維長の差および繊維 自身の柔軟性の差によるものと考えられる。

$\mathrm{AE}$ 自動周波数解析装置にて変換したスペクトラムは 3 種類の夕イプに分けることができた。その識別の結果 を図一12 に示す。type I は卓越した周波数ピークを持 たないもの, type II は 150,250 および $400 \mathrm{kHz}$ にピー クを持つもの,そして, type III は $150 \mathrm{kHz}$ にピークを 持つものおよび $400 \mathrm{kHz}$ に持つものである。

また，これらタイプのスペクトラムをエネルギーの観 点からみると, type I のエネルギーは $0.2 \sim 2 \times 10^{-8} \mathrm{~V}^{2}$ SEC. と低く, type II およびIIIのスペクトラムのエネ

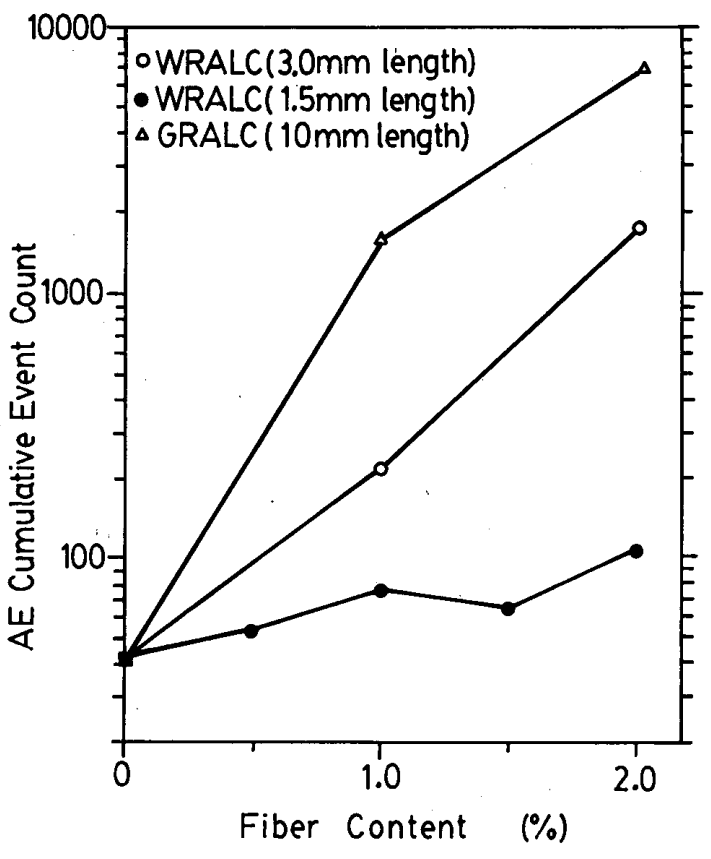

図一11 累積 AE イベント数と繊維添加量との関係

type 1

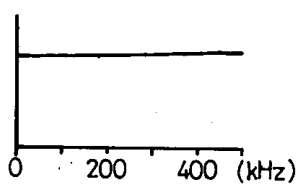

type II

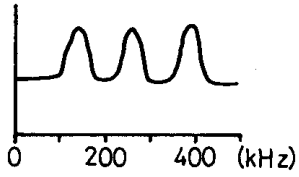

type III

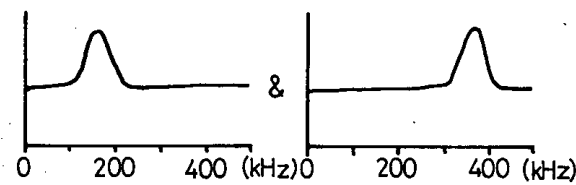

図一12 AE スペクトラムの識別結果

ルギーは広い領域 $\left(0.5 \sim 20 \times 10^{-8} \mathrm{~V}^{2} \mathrm{SEC}.\right)$ にわたつ て発生している。

このタイプ分けをもとに ALC, WRALC および GRALC の荷重曲線上にプロットしたAEタイプ別頻 度分布図を各々図一13，14 および 15 に示す。ここで瀻 維複合 ALCについては一例として添加量 $2.0 \mathrm{wt} \%$ の ものを載せる。

ALC の場合には, type I およびII が発生している。 type I は載荷初期にみられ, type II は最大荷重近辺か ら発生する。しかし, type III はほとんど発生していない。 一方, GRALC および WRALCでは, type I は ALC 上同じように載荷初期から発生する。しかし，そ のイベント数はALC より少なくなっている。それとは 対照的に, type IIのイベント数はALCょり多くなっ ている。また，ALCにはほとんど見られなかった type IIIのスペクトラムが数多く発生している。すなわち，こ 


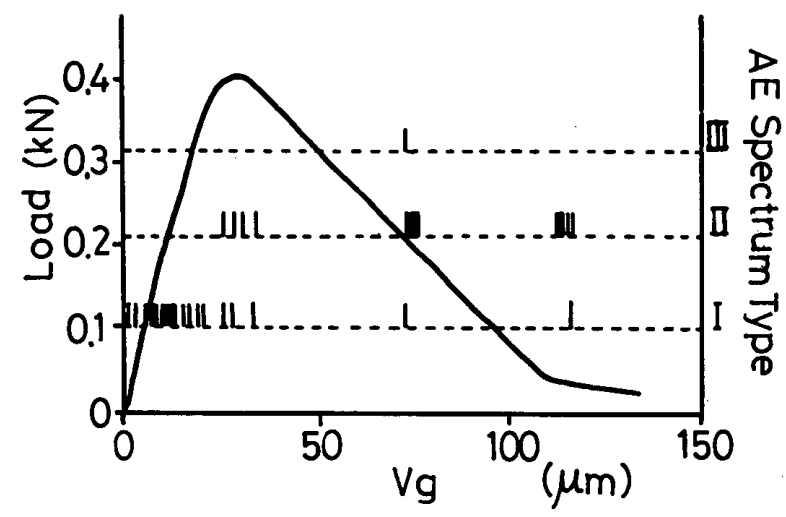

図一13 ALC の AE タイプ別発生頻度分布図

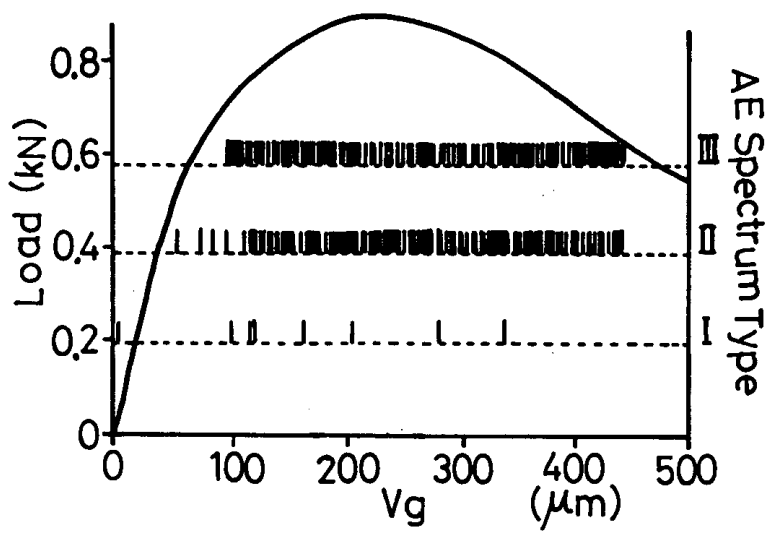

図一14 WRALC（織維長 $3.0 \mathrm{~mm}$, 緎維添加量 $2.0 \%$ ) の AE 夕イプ別発生頻度分布図

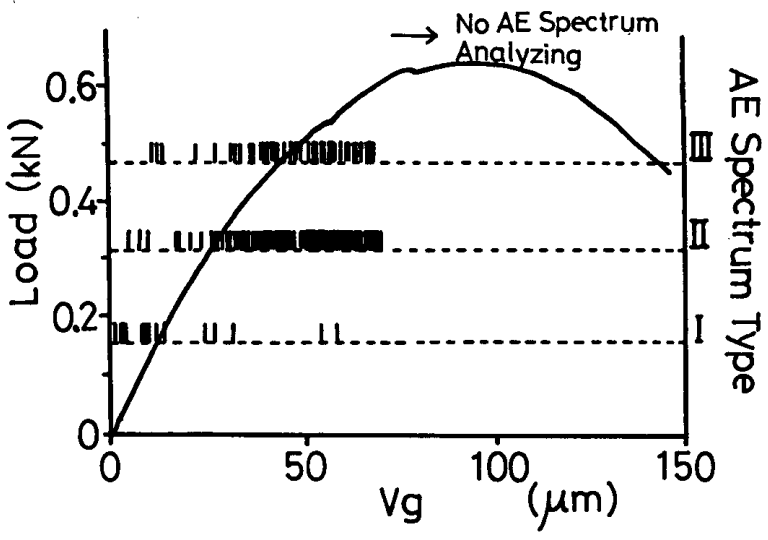

図一15 GRALC（㵶維長 $10 \mathrm{~mm}$, 繊維添加量 $2.0 \%$ ) の AE タイプ別発生頻度分布図

のタイプのスペクトラムは繊維複合によって活性化する ものである。type II および type III の発生は, 非線形挙 動に移行する時点から頻繁に起こっている。

\section{4. 考 察}

写真 $1 ， 2$ および 3 に ALC, WRALC $(3.0 \mathrm{~mm}$ 繊維 長, $2.0 \mathrm{wt} \%$ 添加量) および GRALC (2.0 wt\% 添加量) の破面の電子顕微鏡写真を示す。GRALC, WRALC の両破面から，ほとんどの繊維が抜けているのがわかる。 すなわち, 織維複合 ALC の破壊靶性は繊維とマトリッ クスとの付着によって決まる。
上述の結果から同一添加量での繊維複合効果は 3.0 $\mathrm{mm}$ 繊維長のパルプ繊維が最もよい。1.5 $\mathrm{mm}$ の瀻維の 場合には，ALC に含まれる気泡径が 0.5 1.5 mm であ り，1.5 mm の繊維長では気泡間のマトリックスを補強 するには短すぎるからであると考えられる。そのため， き裂進展開始点でのエネルギーおよび最大荷重点でのエ ネルギーは ALC とほとんど変らない。しかし，き裂進 展抵抗は繊維とマトリックスとの付着のため添加量とと もに向上している。一方, GRALC の場合には, 後述 するように繊維とマトリックスとの付着力が弱いため, 切欠き先端における応力集中域の大きさは ALC とほと んど同じであると考えられる。したがって巨視き裂進展 開始点が ALC とほぼ同じである。しかしながら，繊維 が長いため, 巨視き裂の発生後においては, 繊維の抜け 抵抗によって， $J_{p \max }$ および荷重降下時間を若干増加さ せる結果となっている。

一方, 累積 AE イベント数が WRALC に比して GRALC が多いのは, 使用した耐アルカリガラスの㵶 維自身が長く，繊維とマトリックスとのすべり面が WRALC より大きいために，摩擦による $\mathrm{AE}$ 発生が多 いことと, 図一16に示すように，繊維の配向がき裂に 対して垂直でない場合, 剛性のあるガラス瀻維が, 繊維 方向にそって引抜きが起こるのではなく，マトリックス を破壊しながら抜けるため，マトリックスの破壊に起因 する $\mathrm{AE}$ 発生が多いからであると考えられる。このこ とは, 写真 3 (a) において, 繊維状にマトリックスが 引き抜かれた痕跡が見られることからも明らかである。

上述したようにパルプ繊維と ALC マトリックスとの 付着が耐アルカリガラス㵶維のそれより優れているの は, 繊維自身の親水性, 柔軟性, および表面の粗さによ るものと考えられる。すなわち，第一に，パルプ㵶維は， その親水性および柔軟性によって製造時のスラリー混合 工程でのなじみがよく, その後の発泡工程で気泡内を貫 通することなく，マトリックス内に包含され，添加した すべてのパルプ㵶維がマトリックス内に包含され補強材 として有効に動いている。空隙率が約 $80 \%$ ある ALC にとって，補強繊維が気泡内を貫通していないことが望 ましいのは明らかである。第二に，包含されている緎維 の形態から見てみると, 耐アルカリガラス繊維は直線的 であるのに対し，パルプは曲線的であり，破壊時の㵶維 の抜け抵抗を大きくしている。第三は，繊維の表面粗さ および反応物の付着である。写真 $2(\mathrm{~b})$ より明らかな ように,パルプの表面は粗く，さらに，この繊維のまわ りにはトバモライトが付着しているのがわかる。トバモ ライトの合成は, 熱水雾囲気で行われ, 水の存在が必須 条件である。パルプは製造中に水を多く含んでおり，卜 バモライトの反応に安定した水の供給源となっているた め, 緘維周辺にはよくトバモライトが成長している。一 
方，耐アルカリガラス瀻維の場合，水の含浸性および柔 軟性に乏しく, 写真 3 (a) に示すように, 繊維が気泡 を貫通しており，補強材として十分に機能していない。 さらに, 写真 3 (b) に示すように, 破壊によってマトリッ クスより引き抜かれた繊維の表面にはパルプ繊維ほどの 付着がみられない。

次に, AE スペクトラムから破壊機構を議論する。

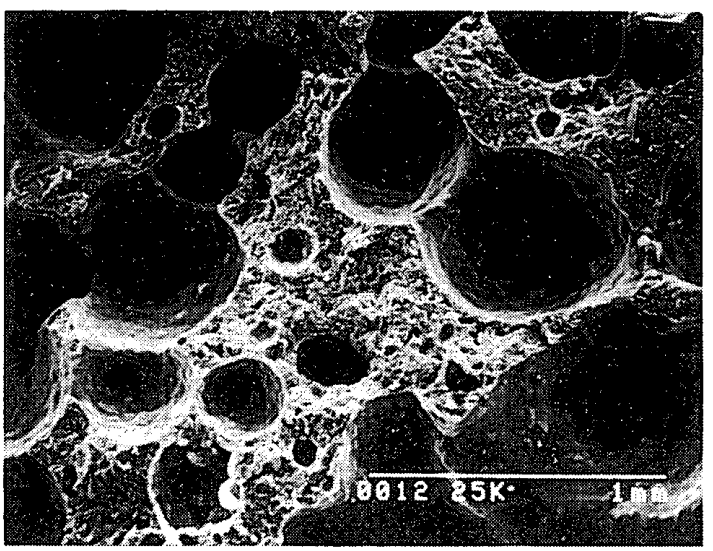

写真一1 ALC の破面写真

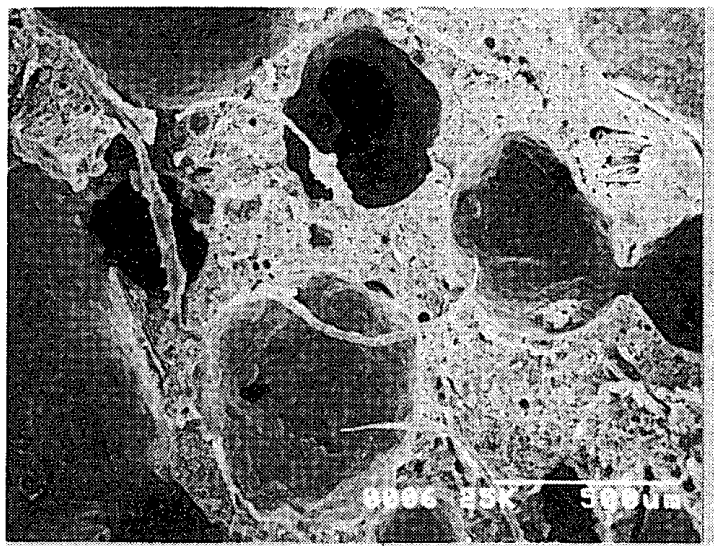

(a)
$\mathrm{ALC}$ の AE スペクトラムは，大きく3つに分けるこ とができる。第一は, 低エネルギーで載荷初期から発生 する type I である。このスペクトラムはマトリックス 中のマイクロクラックの発生に起因すると考えられる。 type I のスペクトラムの発生が繊維の複合効果の増加 とともに減少するのは, 応力開放源が繊維とマトリック との間の剝離に変わるためである。

第二に, type II はマイクロクラック同士の合体，お よびき裂の進展に起因すると考えらる。type II のスぺ クトラムは type I のそれとは対照に繊維添加量の増加 とともに発生量が増加している。これは瀻維の複合効果 によって応力集中領域を増加させていることによる。

第三は，緎維複合した ALC で特に活性な type III で あり，繊維近傍に起こる破壊現象に起因している。繊維 複合 ALC の破壊において, 瀻維が引き抜かれているこ とから，また，引き抜かれた繊維にマトリックスが付着 している部分もあることから，このタイプのスペクトラ ムはマトリックス一䋐維間および繊維近傍のマトリック スに生ずる㔀離およびすべりによるものと考えられる。 以上のことから，図一17 に示すような繊維複合 ALC

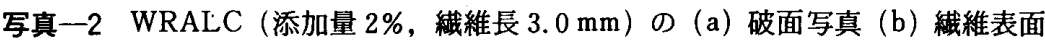

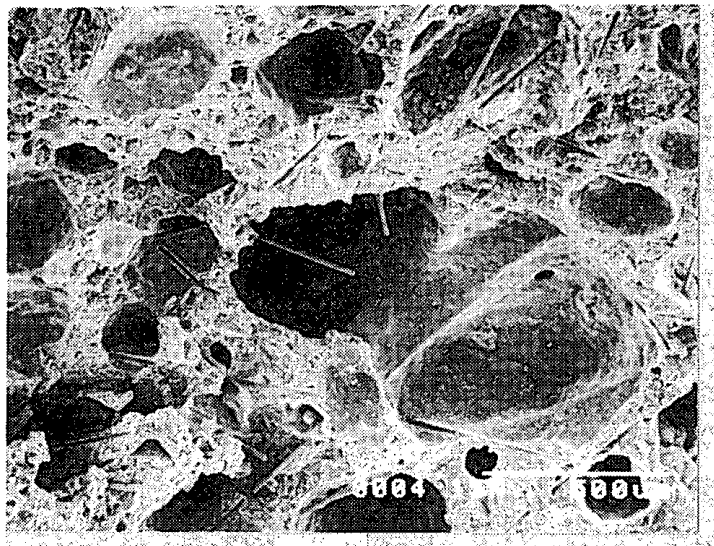

(a)

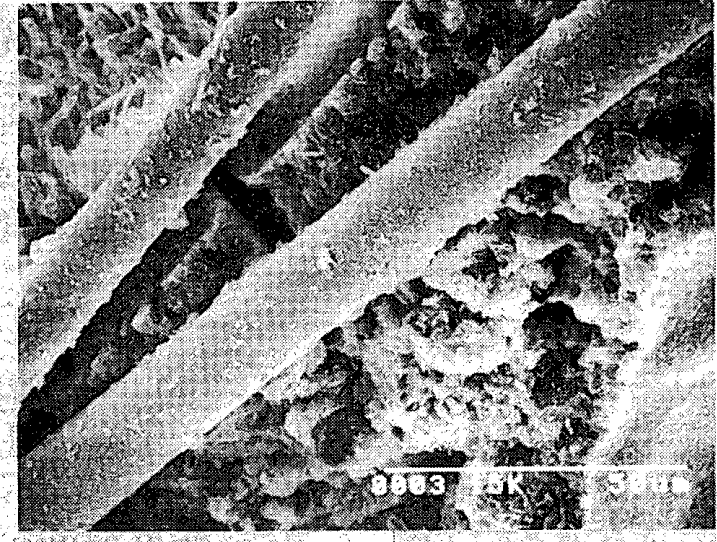

(b)

写真一3 GWALC (添加量 2\%) の（a) 破面写真 (b) 㵶維表面 

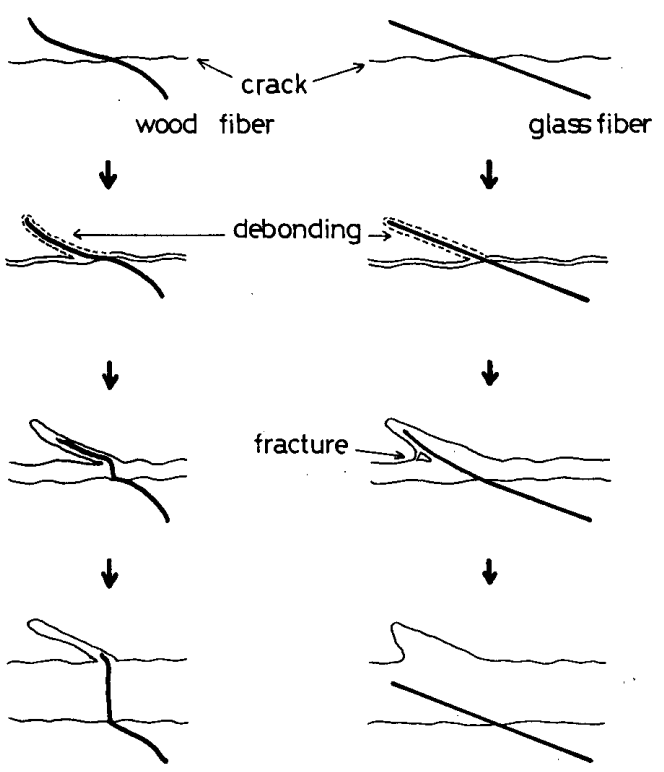

WRALC

GRALC

图一16 WRALC およびGRALCでのき裂に垂直でない繊維 の拔け挙動の差

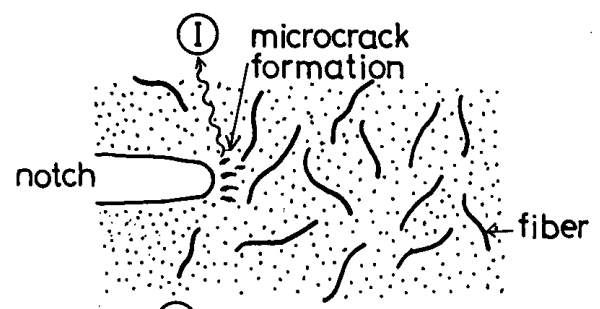

(II)

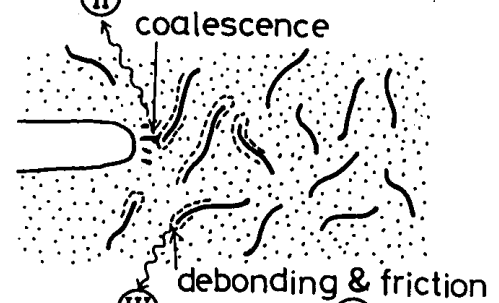

(III)

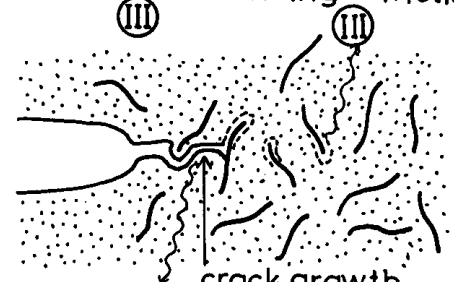

(ii)

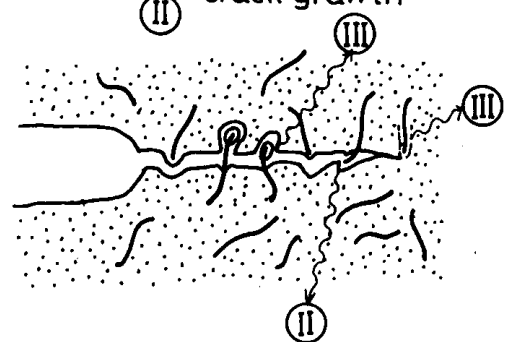

図一17 繊維複合 $\mathrm{ALC}$ の破壊モデルと $\mathrm{AE}$ スペクトラム丸中 のI〜III AE スペクトラムのタイプを現す。

の破壊モデルが考えられる。予き裂先端における応力集 中によってまずその近傍のマトリックス部分にマイクロ
クラックが発生し, type I の AE が発生する。さらに 応力が加わると予き裂先端近傍に存在する瀻維の周囲へ 応力が集中し，その界面にあるいは繊維とマトリックス の付着が強い場合には纎維近傍のマトリックスに剶離が 生じ, type III が発生する。同時にマトリックスでのマ イクロクラック同士の合体が起こり, type II が発生す る。さらに応力が加わると瀻維近傍のすべりによって type III が, メインクラックの進展によって type II が発 生する。したがって，繊維複合 ALC の巨視き裂の進展 に起因する AE スペクトラムは type II および IIIであ る。このような観点からあらためて図一14 と図一15 の AEタイプ別頻度分布をみると type IIおよび吕の初期 発生は WRALC に比して GRALC のほうが早く, $J_{I A E}$ の傾向と同じである。

\section{5. 結 言}

上述してきたことをまとめると，

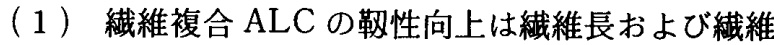
とマトリックスとの付着力の強さによる。この両者の要 因はき裂先端の応力集中域の大きさを決定するものであ る。

（2）繊維複合 ALC の AE スペクトラムは 3 種類の タイプに識別できた。

(3) type I はマイクロクラックの発生によるもの であり, type II はマイクロクラックどうしの合体およ びき裂の進展によるもの, type III はマトリックス一織 維間および瀻維近傍のマトリックスの剝離およびすべり によるものである。

（4）巨視き裂に起因するAE スペクトラムはALC の場合は type II のみであり, 瀻維複合 ALC では type II と III が相当する。

\section{謝 辞}

本研究を行うに際し，ご指導を頂きました東北大学工 学部附属材料強度研究施設高橋教授, 小野田セメント

（株）建設材料研究所梘山主研，ならびに小野田エー。 エル・シー（株）群馬工場大場工場長に心から感謝いた します。さらに本研究において用いた自動 $\mathrm{AE}$ 周波数 解析装置の使用の機会を与えていただきました新技術開 発事業団，ならびに旭化成工業（株）システムエンジニ アリング研究所の関係各位に心から謝意を表します。

注

自動 $\mathrm{AE}$ 周波数解析装置は新技術開発事業団開発プロジェク 卜「周波数解析による $\mathrm{AE}$ 計測システム」の開発委託の一環で, 旭化成工業（株）が開発試作したものである。

\section{引用文献}

1）小林一輔：緎維補強コンクリート一特性と応用一, (1981), オーム社

2）宮本 博ほ加：日本機械学会基準弹塑性破壊勒性 $\boldsymbol{J}_{I C}$ 試 
験方法，(1981），財団法人日本機械学会

3）國尾 武ほか：破壊力学実験法, (1984), 朝倉書店

4) F.H. Wittmann : Fracture Mechanics of Concrete, Elsevier, 1983

5) D.D. Iggins and J.E. Bailey : Fracture Measurements on Cement Paste, J. of Materials Science, No. 11, 1976

6) Yu. V. Zaitsev and K. L. Kovler : Notch Sensitivity of Concrete and Size Effect-Part 1, Effect of Specimen Size and Crack Length by 3-Points Bending, Cement and Concrete Research, Vol.15, 1985

7) H.W. Reinhardt : Crack Softening Zone in Plain Concrete under Static Loading, Cement and Concrete Research, Vol. 15, 1985

8) B.I.G. Barr, E. B. D. Hasso and B. B. Sabir: The Effect of Test Specimen Size on the Fracture Toughness of Concrete, Cement and Concrete Research, Vol.15, 1985

9）和泉正哲, 三橋博三：コンクリートの破壊に関する研究 の新しい動向, セメント・コンクリート, No. 423, 1982

10) F.H. Wittmann and I. Gheoghita : Fracture Toughness of Autoclaved Aerated Concrete, Cement and Concrete Research, Vol.14, 1984

11）丹羽義次, 小林昭一, 大津政康：コンクリート構造物の アコースティック・エミッション特性に関する基礎的研 究, 土木学会論文報告集, No. 261,1977

12）富士 岳：コンクリート中の $\mathrm{AE}$ の挙動, 非破壊検査,
No. 10, 1985

13）丹羽義次，小林昭一，大津政康：アコースティック・エ ミッションによる破壊源探査, 土木学会論文報告集, No. 276,1978

14）新妻弘明, 高橋秀明, 中鉢憲賢：周波数にもとずく $\mathrm{AE}$ 発生パターンの分類と微視破壊過程, 非破壊検査, No. 30 , 1981

15）寺村敏史, 梘山興一, 高橋秀明, 新妻弘明：AE 自動周 波数解析装置によるセメントモルタルの微視破壊過程の 解析, 石高亡石灰, No. 200, 1986

16）鈴木正彦, 萩野 温, 海野紘治：アコースティック・エ ミッション法による木材の乾燥割れの予知, 日本機会学 会誌, Vol. 88, No.798, 1985

17）新妻弘明，中鉢憲賢：AE 法による設備診断と品質管理, 第 9 回応用情報額研究センター・シンポジウム予稿集, 1984

18）近藤連一ほか：石灰けい酸系水熱反応，セメント技術年 報, X X I , 1967

19) H. Niitsuma, N. Chubachi, M. Kameyama, H. Higuchi and J. Konno: Real-Time AE Spectrum Analyzer Using a New Pipelined FFT Processor, Proc. the 6 th International Acoustic Emission Symposium, 1982

20）新妻弘明, 中鉢憲賢, 車山充隆, 桶口龍雄, 今野淳一： 自動 $\mathrm{AE}$ スペクトラム解析装置, 非破壊検查協会 006 特 別委員会資料, No. 68,1983

\title{
SYNOPSIS
}

UDC : $691.32: 666.973 .6$

\section{FRACTURE TOUGHNESS AND ACOUSTIC EMISSION SPECTROSCOPY OF FIBER REINFORCED AUTOCLAVED LIGHTWEIGHT CONCRETE}

\author{
by SATOSHI TERAMURA, Member of A. I. J
}

The fiber reinforced Autoclaved Lightweight Concretes (ALC) produced by using the wood fibers and the alkaline-resistance glass fiber were evaluated the fracture toughness by notched 3-points bending test. In addition, the spectrum of acoustic emission (AE) events detected during deformation were analyzed and were classified. The classified spectrum types were correlated with the fracture mechanism.

Most of fibers were pulled-out during fracture. Toughness of fiber reinforced ALC, therefore, depends upon fiber length and bonding strength between fiber and matrix. It is considered that bonding strength of wood fiber is larger than that of alkaline-resistance glass fiber. Reinforced ALC using wood fiber of $3 \mathrm{~mm}$ length is tougher than one using alkaline-resistance glass fiber of $10 \mathrm{~mm}$ length.

AE spectrum were classified into three types by the frequency component. First spectrum group (type I) which had low energy occurred from the early stage of loading. Type $I$ is caused by the microcrack formation in the matrix. Second group (type II ) and third group (type III) which had a very wide distribution of energy occurred from non-linear behavior. Type II is caused by the coalescence among microcracks or by the crack propagation. Type III which is peculiar to fiber reinforced ALC is caused by the debonding and the friction around fiber. 